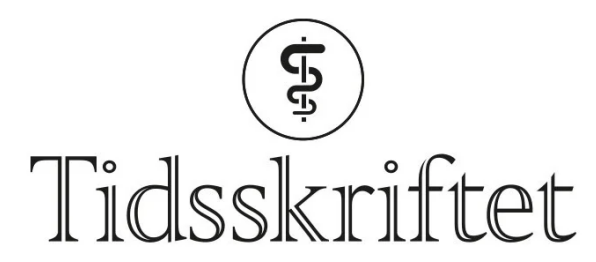

DEN NORSKE LEGEFORENING

\title{
Sårtilheling uten arrdannelse
}

FRA ANDRE TIDSSKRIFTER

HAAKON B. BENESTAD

Universitetet i Oslo

\section{Ved å hemme aktivering av et gen som styrer arrdannelse, tilhelte hudsår i mus uten arr.}

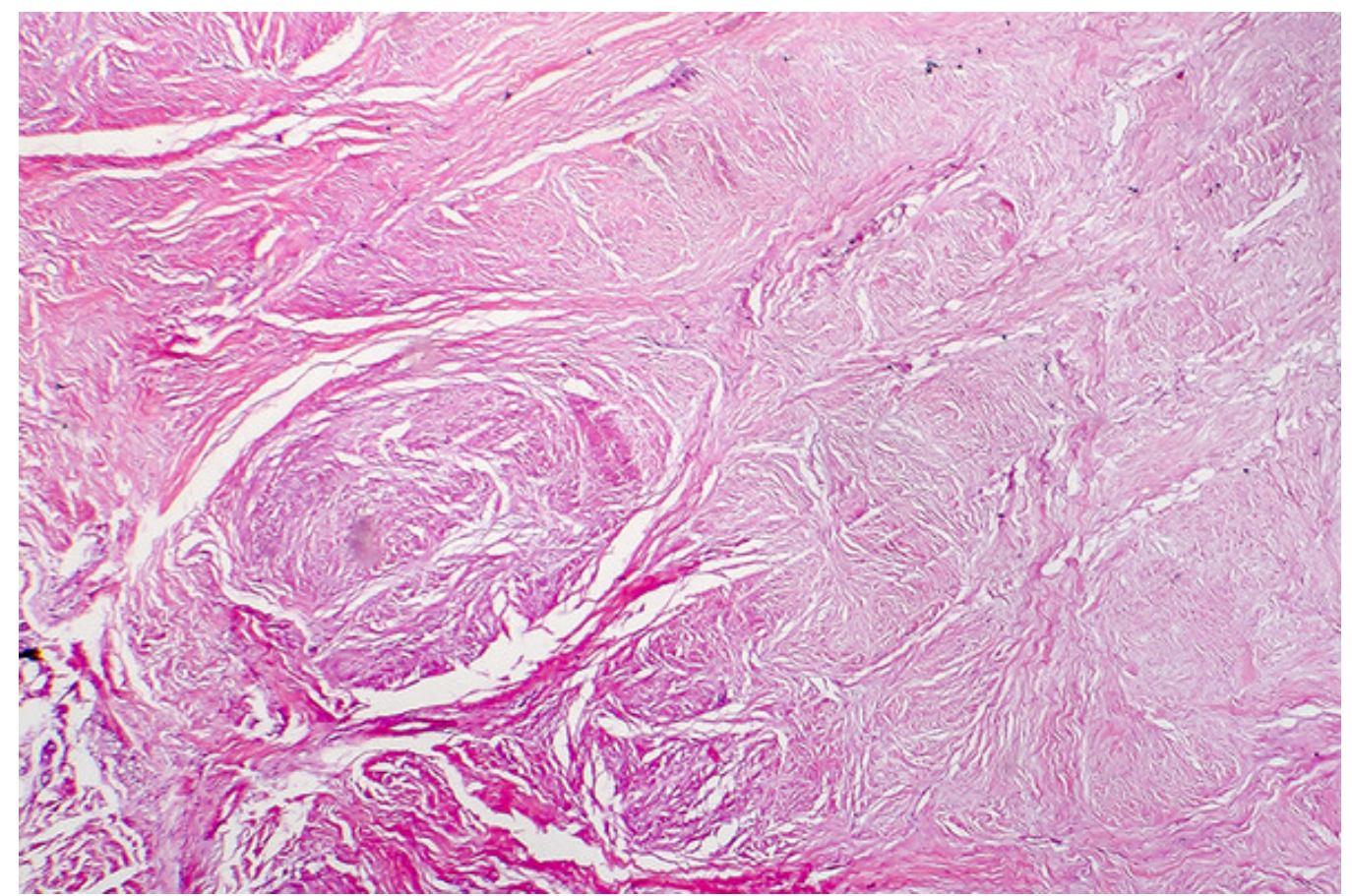

Fibrøst vev. Illustrasjon: Dr Microbe / iStock

Noen laverestående vertebrater og invertebrater kan gjendanne funksjonelt vev hele livet uten arr, mens vev i mus og mennesker repareres med arrdannelse. Denne reparasjonsevnen kan ha vært en evolusjonsbiologisk fordel.

Genetisk analyse av enkeltceller har vist at fibroblaster har egenskaper som varierer mellom ulike organer og innen samme organ. Fibroblaster i dermis i pattedyr kan være både med og uten aktivering av engrailed-1 (EN1)-genet, som styrer andre aktive gener under arrdannelse. 
I en ny studie ble EN1-negative fibroblaster positive under arrdannelsen etter hudsår i mus (1). Jo større mekanisk påkjenning såret ble utsatt for under tilhelingen, jo mer arrvev ble dannet og jo mer omfattende ble omdannelse av $E N_{1}$-negative til EN1-positive fibroblaster. Genet ble aktivert ved strekk av huden og når de $E N 1$-negative fibroblastene ble dyrket på stiv plast, men ikke på en bløt gel. Integriner i cellemembranen signaliserte aktiveringen via en signalkjede som ender i transkripsjonsfaktoren YAP-proteinet. Dette ble vist ved å hemme transkripsjonsfaktoren farmakologisk med verteporfin (som brukes mot aldersrelatert makuladegenerasjon) og med fibroblastspesifikk knockout av YAP-proteinet.

Tilheling av hudsår med EN1-negative fibroblaster tilfredsstiller de tre normalitetskriteriene for regenerasjon: (i) tilhelet hud med hår og talgkjertler, (ii) matriksarkitektur med kollagenfibre i kurvfletningsmønster og uten de tykke, parallelle kollagenfibrene som finnes i arr, og (iii) strekkresistens og fleksibilitet som i uskadet hud og med normal ekstracellulær matriksstruktur.

- Dette er spennende funn av potensielt stor betydning for flere medisinske fagfelt, ikke minst generell og kosmetisk kirurgi, sier Sigbjørn Fossum, som er professor emeritus ved Institutt for medisinske basalfag ved Universitetet i Oslo.

- Med tanke på at det aktuelle genet er uttrykt i flere typer vev - det er blant annet sentralt i utvikling av nervesystemet - kan det også ha betydning ved regenerering etter skader av andre vev, som for eksempel ryggmargen, sier Fossum.

\section{LITTERATUR}

1. Mascharak S, desJardins-Park HE, Davitt MF et al. Preventing Engrailed-1 activation in fibroblasts yields wound regeneration without scarring. Science 2021; 372: eaba2374. [PubMed][CrossRef]

Publisert: 26. juli 2021. Tidsskr Nor Legeforen. DOI: 10.4045/tidsskr.21.0421

(C) Tidsskrift for Den norske legeforening 2023. Lastet ned fra tidsskriftet.no 26. april 2023. 